Finanse, Rynki Finansowe, Ubezpieczenia nr 4/2016 (82), cz. 2

\title{
The Impact of Financial Governance on Profitability in Jordanian Commercial Banks (During the Period 2004-2013)
}

\author{
Abdul Nafea Al Zararee, Ola Sinno*
}

\begin{abstract}
The aim of this study is to know the extent of the application of financial governance on Jordanian commercial banks. The study also aims to measure the effect of financial governance on the profitability of such banks throughout the use of some tools of financial governance such as the ratio of financial adequacy, financial leverage, loans to deposits, capital adequacy to deposits, net profit margin, and coverage ratio. The study consists of thirteen Jordanian commercial banks. As regards, the sample of the study, it includes three commercial banks whose capitals range between small, middle, and large during the period 2004-2013. To realize the goal of the study, the SPSS is applied to analyze the data of the study. The study depends on financial data taken from the yearly reports of the banks of the sample as they are issued on the electronic website of the Amman Stock Exchange. This study has been carried out with meta-data extraction, and standard deviations to test the normal distribution of the data. Moreover, Pearson's correlation matrix tests the stability of the data for the study and variables are achieved. Finally this study adopts a simple linear regression and multiple analysis and the testing of the random effect of the hypotheses.
\end{abstract}

Keywords: profitability, commercial banks, financial governance

\section{Introduction}

The global financial crises that affected the greatest economies of the world do not happen randomly and/or momentarily. They appear as a result of so many wrong practices and usages that last for long periods of time, such as the malfunctions of the administrative authentic bodies and organizations, lack of transparency, in addition to poor governmental observation and censorship. The problem of agencies and other aspects of administrative is the corruption that have negative effects and results on business organizations or corporations in general and the financial ones in particular.

Accordingly, almost all administrative and financial establishments/corporations look forward to finding solutions that may help them get rid of the negative impacts of crises the traces of which are still apparent in the world. The concept of 'Governance' appears in the world of business in a strong way in the frame of the efforts exerted by the different international bodies and organizations in the field of the humanitarian political, economical

\footnotetext{
* dr Abdul Nafea Al Zararee, Head Department of Banking\& Finance, Philadelphia University of Jordan, e-mail: aalzarari@philadelphia.edu.jo; Ola Sinno.
} 
and social development. That is, a great number of organizations/corporations hardly try to apply their principles in an accurate way, and to put the bases of adequate administration and management in order to get rid of the negative impacts of the financial crises (Hammad 2005).

Of course, under such critical circumstances that face corporations, the concept of 'Corporations' Governance' comes to be one of the main interests and basic issues for business societies and all aspects of the economy. Business societies start to learn and re-learn the lesson of that there is no alternative that suffices the essential systems of business and financial management and place them in the position of application or execution. As so, such business works and actions are able enough to succeed and compete in all local and international levels (Hammad 2005).

\section{Problem of the Study}

The care of governments and establishments in general and the financial corporations in particular toward governance as a solution that leads to guidance paths of improving performance increases as a reaction to aspects of administrative and financial corruption, irresponsible administrative applications and actions, and weak observation and follow-up.

The importance of governance application in the bank sector refers to the fact that banks are the first source of financing individuals and corporations as well. Moreover, banks play a very important role in the process of censoring the corporations they finance. One more important role of banks is their financial backing of economic development through gathering all the different resources and orienting them toward suitable use and investment. One should not forget that the safety, development and continuation of the banking sector are important and necessary for the future of an economy, and that any crises and cases of bankruptcies in this very sector create continuous problems and difficulties (Sya'm 2009).

Taking what has been mentioned above into consideration, it becomes possible to direct the following question: Do commercial banks apply and conform to the principles of financial governance as an effective means of improving performance? If the answer is 'Yes', the real question will be: What is the extent of the application of the principles and criteria of financial governance in commercial banks, and what is its impact on profitability?

\section{Objectives of the Study}

To answer the questions of this study, a group of objectives has been put forward; these include:

1. Knowing the concept of 'Governance': its emergence, characteristics, criteria, importance and limits.

2. Acquainting with the essence of bank governance: its features, significance, and the factors necessary for the good application of governance. 
3. Clarifying the role played by financial governance in improving the financial performance of commercial banks.

4. To be aware of the results of the good application of the principles of financial governance in commercial banks.

\section{Importance of the Study}

The world witnesses so many universal financial crises the effects of which are still standing at present. These crises are the result of the wrong administrative practices of the business corporations or organizations for a long time of administrative and financial corruption and irresponsible administrative practices, in addition to the weak observation and follow-up. The crisis of business banks in Wall-Street results in the emergence of the huge Brothers Investment American Bank because of the loss which happened in the markets of real estate mortgaging. This is a dangerous symbolic start, since this ancient corporation is one of a few organizations which escape from the massacre of the great stagnancy of 1929. All this leads such corporations and bodies to call for solutions to save them from such crises and their negative effects.

The importance of this study emerges from the significant variables it discusses. It sheds light on the concept of 'Governance' and its role in getting rid of financial crises and their impacts which still shadow the entire world nowadays. It also focuses on the importance of governance in improving financial performance (Abu-Sharar 2012).

\section{Pattern of the Study}

The pattern of the study consists of the following variables.

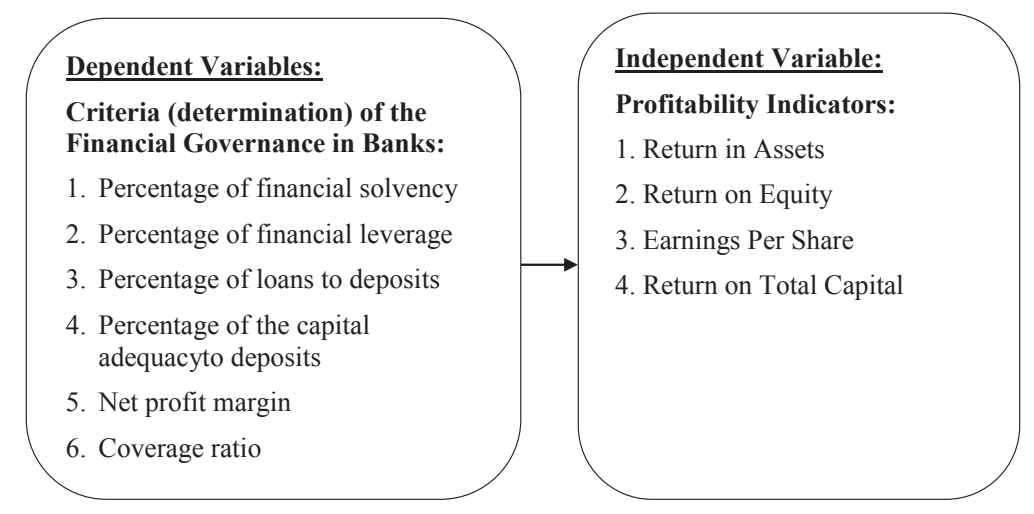

Figure 1. Criteria (determination) of the Financial governance in Banks and profitability indicators 


$$
\begin{gathered}
Y=f(X 1, X 2, X 3, X 4, X 5, X 6) \\
Y=a+b 1 x 1+b 2 \times 2+b 3 \times 3+b 4 \times 4+b 5 \times 5+b 6 \times 6+e
\end{gathered}
$$

As:

Y: Return on Total Capital

A: Constant

B: regression coefficients

$\mathrm{X} 1$ : Financial solvency

$\mathrm{X}$ 2: Financial leverage

X3: Percentage of loans to deposits

$\mathrm{X} 4$ : Percentage of the capital adequacy to deposits

X5: Net profit margin

X6: coverage ratio

E: Mean of random change.

This study adopts the return on total capital as a variable that indicates the profitability of commercial banks considering that it is possible to choose whichever of the variables of profitability which is not a matter of analysis, so as to avoid repetition.

\section{Module Description variables}

\section{Independent Variables:}

1. Ratio of Financial adequacy: This ratio applies as a tool of evaluating the extent of the company (bank) capability to fulfill their long term obligations. It also measures the extent the success of its financial policies throughout the balance between the internal and external financing sources, and the reflections of such policies on the financial leverage risk. As regards banks, it measures the extent of the bank's ability to protect its depositors and investors funds. The increase in this ratio will have a positive impact on the bank where increasing deposits also increased profitability (Stickney 1990).

$$
\text { Ratio of Financial adequacy }=\frac{\text { Equity }}{\text { Deposits }} \times 100
$$

2. Ratio of Financial Leverage: This ratio measures the relation between the assets of the bank and the equity. The increase of this ratio is the more it indicates that the bank greatly depends on debt to finance its assets (Stickney 1990).

$$
\text { Ratio of Financial Leverage }=\frac{\text { Total Assets }}{\text { Equity }} \times 100
$$


3. Ratio of Loans to Deposits: This ratio measures the extent of the administration success in employing bank deposits in operations that bring the highest profits. That is the extent of the bank deposits contribution in providing its customers with loans (Stickney 1990).

$$
\text { Ratio of Loans to Deposits }=\frac{\text { Loans }+ \text { Facilities }}{\text { Total Deposits }} \times 100
$$

4. Ratio of Capital Adequacy to Deposits: It is an indicator that refers to the capability of the bank to pay deposits up (Stickney 1990).

$$
\text { Ratio of Capital Adequacy }=\frac{\text { Liquid Asset }}{\text { Turnover of Deposits }} \times 100
$$

5. Net profit Margin: This ratio reflects the activity of the working operations and their efficiency. What is logical is that whenever the margin increases, the operation performance of bank administration improves, and it is vice versa (Stickney 1990).

$$
\text { Ratio of Net Profit Margin }=\frac{\text { Net Profit }}{\text { Sales }} \times 100
$$

Where the sales of banks (as service corporations) are represented by the loans bank facilities for the target groups.

6. Coverage ratio: It is a compound indicator developed throughout the indicator of the capital (i.e., equity), where calculate by capital plus loan reserve minus bad loans to the total assets. It helps to say whether the bank is fragile (Stickney 1990).

Coverage ratio $=\frac{\text { The Capital }+ \text { Loan Reserves }- \text { bad Loans }}{\text { Assets Reserves of Loans }=\text { Optional Reserves }+ \text { Other Reserves }} \times 100$

\section{Dependent Variable:}

Return on Total Capital (ROTC): This is one of the ratios of profitability which measures the profit achieved by the company throughout the employment of its total capital (Debt and Equities) (Stickney 1909).

$$
\text { Return On the Total Capital }=\frac{\text { Earnings Before Interest and Tax }}{\text { Total Capital }} \times 100
$$

This study attempts to apply the model study sample on Jordanian commercial banks as an applicable state when data about such banks are available. 


\section{Hypotheses of the Study:}

\section{The Main Hypothesis}

There is no relationship with a statistical significance between the financial governance and the profitability of the commercial banks in Jordan.

\section{Subordinate Hypotheses:}

1. First Hypothesis: There is no relationship with a statistical significance between the financial adequacy and the profitability of the commercial banks in Jordan.

2. Second Hypothesis: There is no relationship with a statistical significance between the financial leverage and the profitability of the commercial banks in Jordan.

3. Third Hypothesis: There is no relationship with a statistical significance between the loans to deposits and the profitability of the commercial banks in Jordan.

4. Fourth Hypothesis: There is no relationship with a statistical significance between the capital adequacy to deposits and the profitability of the commercial banks in Jordan.

5. Fifth Hypothesis: There is no relationship with a statistical significance between the net profit margin and the profitability of the commercial banks in Jordan.

6. Sixth Hypothesis: There is no relationship with a statistical significance between the coverage ratio and the profitability of the commercial banks in Jordan.

\section{Methodology of the Study}

The current study adopts the descriptive analytic method to test the above mentioned hypotheses. It considers the previous literature and theories as sources of the study.

\section{Sample and Society of the Study}

The society of the study consists of 15 Jordanian banks thirteen of which are commercial and the other two are Islamic. As regards its sample, the study depends on three intended Jordanian commercial banks. One of them is of a large capital; the second is of an intermediate capital, whereas the third one is a small capital.

\section{Method of Data Collecting}

For the purpose of gathering data related to the period of 2004-2013, this study depends on secondary sources, i.e., the financial statements of banks in its sample. Such lists are available on the electronic website of the Amman stock market: (http://www.ase.com.jo/ar).

\section{Review of Literature}

1. The study of Yahyawi and Bu Salama (2012) entitled with The Role of Establishment Governance in Improving the Financial Performance of Corporations, aims at shedding 
light on the role carried out by the establishment governance in improving the financial performance of companies throughout knowing the concept of 'Establishment Governance', its goal, limits, basic principles and the parties involved in it. The study arrives at a group of conclusions the most important of which is that the companies which apply the establishment governance become more attractive to investors, and that leads to an increase in the entrance to the financial markets, affluence of credit, reduction in the cost of finance, increase of the market value of the company, reduction of risks, increase the competition of the company, facing corruption and afflux of capitals.

2. The study of Syam (2009) entitled with The Role of Banking Governance in Enhancing the Competence of Jordanian Commercial Banks, aims at measuring the importance of the application of professional banking governance. It ends with a group of conclusions and recommendations the main of which are that banking governance has succeeded in attracting attention and enhancing the competence of Jordanian commercial banks, emphasis of observation of the processes of facilities according to administrative and legislative frames that reflect the bright image of banking governance during the time of globalization and its reflection on enriching the competence of Jordanian commercial banks.

3. The study of Al-Shunnaq (2009) the title of which is Announcing the Governance of Corporations and the Financial Performance: An Applied Study on Jordanian Commercial Banks, attempts to limit the level of the obligatory and optional announcement of the information related to the governance of companies in the yearly financial reports of Jordanian commercial banks and their financial performance during the period 2008-2011. The sample of the study consists of 13 Jordanian commercial banks. The study concludes that the level of the general announcement, whether obligatory or optional, of governance of corporations is high in their yearly financial reports; whereas the level of the optional declaration/ announcement of governance of corporations in their yearly financial reports is higher than the obligatory one. It also recommends that more attempts at academic studies on this topic are very necessary.

4. The study of Jawdah (2008) titled with The Extent of the Application of the Principles of Establishment Governance in the Palestinian Banks in Accordance with the Principles of the Organization of Development and Economic Cooperation, and the Principles of Basel Organization of Bank Censorship, aims at knowing the reality of the establishment governance in the Bank of Palestine according to the principles of the above mentioned organizations. The group of the study contains 36 positions the names of which range between (member of the board of directors, executive manager, internal auditor, and external auditor). The study arrives at a group of conclusions the main of which is that the application of the principles of the establishment governance positively affects the indicators of bank performance. The study also puts some recommendations the main of which is the one that calls for developing the operations of Palestinian monetary authority in the field of the establishment of governance. It also recommends that the Council of the Bank Administration is to form a specialized committee for the management of risks. 
5. The study of Matar and Noor (2007) the title of which is The Extent of the Commitment of the Jordanian General Sharing Corporations in the Principles of the Establishment of Governance is intended to discover the extent of such a commitment by such companies. It suggests a general frame to a system of establishment governance in the Jordanian corporations. The study adopts a questionnaire for the purpose of collecting data, in addition to personal interviews with some responsible personalities of banks and industrial corporations which are registered in the Amman stock exchange. These personalities constitute the sample of the study. The study concludes that that the level of commitment of such companies in both banking and industrial sectors ranges between strong and weak levels with priority to the banking sector. The researchers attribute that to the inspective role played by the Central Bank in verifying the principles of the establishment governance in these banks. It also measures the adherence of the banks on their commitment to the resolutions of the Basel committee. Moreover, the study concludes that the poor application of the establishment of a governance system refers to the spread of the phenomenon of information infiltration or leakage and spread of rumors that some administrations practice in some companies. This leaves negative effects and traces on the climate of investment in the financial market. The researchers recommend the concerned authorities in both banking and industrial sectors of the importance of the application of the system of establishment governance and activate the role of the committee of scrupulousness giving it more and more administrations and auditors to commit the principles of professional behavior and stop any unprofessional practices especially those ones that relate to the phenomenon of infiltrating private information and spreading rumors that contradict the principle of announcement.

6. The study of Abdul-Haleem (2005) the title of which is Governance of Banks was aimed at measuring the extent of Sudanese banks' application to the establishment of governance and it showed the importance of such an application for the Sudanese banking system. The researcher applies a questionnaire as a study tool. He limits the study to all the national banks operating in Sudan. The study concludes that the Sudanese banks apply the principles of establishment governance mentioned in the resolutions of the Basel Committee and the instructions of The Sudanese Central Bank in their banking supervision.

7. The study of Al-Hanini (2004) which is titled with Developing the System of corporate Governance in the Jordanian Shareholders companiesis is an attempt to develop this system and apply it in such corporations. Doing so, it aims at enhancing the independence of the lawful auditor and tests the extent of his cognition of the competence of the above mentioned system applied in these corporations. It also measures the impact of this system on the auditor's competence.

The data of the study are gathered through a questionnaire distributed to the entire study sample represented by 120 working auditors, in addition to the personal interviews with a group of auditors. The study concludes that the Jordanian auditors have a level of good cognition of the concept of corporate governance. It also shows that there is real concern to 
study and evaluate the competence of the corporate governance system. In conclusion it can be stated that such a system positively affects the auditor's independence.

\section{Features of the Study}

Previous studies have tackled the topic of corporate governance from different aspects of different values. Other studies investigated the impact of its application of corporate governance on the indicators of the corporations' performance and the quality of their financial reports and announcement. It is worth mentioning that all the previous studies did not try to deal with the reality of financial governance in the Jordanian banking sector.

On the contrary, with previous studies, the most important characteristic of this study is that it tackles the topic of financial governance in banks. It can be regarded as being the first study that has investigated this topic. As regards financial governance and profitability, many new variables are actually involved.

\section{Factors Necessary for the Application of Good Governance in Banks:}

The main plans, good governance in banks include, are the following (Al-Khalidi 2008):

- Putting values, principles and criteria to control the manners of work and financial performance.

- Putting plans, policies and techniques to evaluate the performance of banks and their workers/employees.

- Limiting the authorities and responsibilities of decision-taking from the level of board of director to the low administrative and executive levels.

- Finding a mechanism of coordination and between the board of director, the executive administration and auditors.

- Having a strong system of internal censorship and control that includes internal and external audits, and independent administration to risks, checking and balancing and continuous monitoring of the transactions.

- Censoring and controlling credit risks of related parties and big borrowers, shareholders, managers, and decision-makers in the corporation whose interests are interacted.

- Having an administrative and financial system of motives in all sectors.

As regards the factors that should be available for the application of good governance in banks, these include:

1. The Central Bank should issue rules of censorship related to the establishment of governance. Such rules should be accepted and recognized by all relevant parties (Sulaiman 2006), (Al-Ghunaimi 2005).

2. The administrative councils and administrations of banks should have enough satisfaction in the importance of these rules and restrains in such a way that helps to carry them out. 
3. There should be a clear strategy on the base of which the extent of a bank's success can be measured, and the extent of the participation of administration and individuals in this success.

4. The ascertainment of the competence of the administrative council members and the diversity of their experiences and complete cognition of the concept of governance. One other necessity is the availability of suitable levels of testing and follow-up inside the bank.

5. The necessity of having suitable levels of testing and follow-up inside every bank.

6. It is necessary that transparence and announcement are available in all the work and activities of the bank and its administration.

\section{Governance as a System of Evaluating Bank Performance:}

Many international systems appear and try to evaluate the performance of commercial banks as a system of classification CAMEL which depends on five elements (Rose 2002); these are: $\mathrm{C}$ - Capital adequacy, $\mathrm{A}$ - Asset quality, $\mathrm{M}$ - Management quality, E - Earnings, $\mathrm{L}-$ Liquidity.

Similarly, the system of evaluation CRAFTE limits the type of evaluation and the degree of dangers and the entire quality of banks throughout its sixteen elements that indicate to (Rose 2002): C - Corporate governance, R - Risk management, A - Asset Quality, F - Financial leverage - Capital and Liquidity, $\mathrm{T}$ - Transparency, E - Earnings.

Governance is considered to be an effective system of control in the banking sector and in evaluating the performance of banks. But, this system does not find enough care and concern and is not put in the position of application. Hence, this study adopts the topic of financial governance as a system one can rely on to evaluate the performance of banks throughout the application of principles and criteria which stand for the most effective factors of governance as applicable criteria. However, some of these criteria have not been tackled by studies yet.

\section{Banks in Brief}

\section{The Arab Bank}

The Arab Bank is a Palestinian origin bank. Its headquarters were transferred to Jordan, and so it became a Jordanian bank. It was established by Abdul Hameed Shoman in Jerusalem/Al-Quds in 1930. It started with a start-up capital of 15,000 Palestinian pounds. Seventy years later, it has become an international establishment and one of the biggest Arab banks with capitals of 27.31 Million US dollars in 2005. Its profits were 310 million US dollars. Today, the Arab Bank Group has branches spanning 5 world-wide continents. 


\section{Jordanian Ahli Bank}

This is a bank which was founded in Amman in 1955. It is considered to be the first ever Jordanian bank. Its start-up capital was 350,000 JD. It plays an important role in serving individuals and the national economy as a whole. It is not merely a financial establishment that aims at earning; it is rather a bank that tends to raise the Jordanian citizens' awareness as regards the culture of saving, and the culture of banks and their policies. Its service to people and companies has lasted for more than 50 years. Together with other banks, it helps to improve the national economy.

\section{Jordan Kuwaiti Bank}

Thist is a Jordanian bank which was established in Amman as a joint investment of Jordanian and Kuwaiti investors, and other investors from other Arab countries. Its start-up capital was 5 million JD in 1976, the year it was founded. Nowadays, it has 59 Jordan-wide branches. Moreover, it has some branches in Palestine and Cyprus. It is regarded as one of the few successful projects that were established with joint Arab sharing or contributions.

\section{The Tools of the Study}

This study depends on such financial ratios as: Financial adequacy, financial leverage, loans to deposits, capital to deposits, margin of net profits, coverage rate, and return on total capital). Such ratios are based on the data actually collected from the yearly financial reports of banks during the period 2004-2013.

\section{Data Analysis}

In accordance with the topic of this study, data and information gathered from the financial reports and official statistics will be analyzed through the direct process of analysis for the years 2004-2013, and the counting out of Independent Variables Affecting Earnings in the three banks.

Application of the criteria (ratios) of financial Governance in the study sample banks:

\section{Table 1}

Criteria of the Financial Governance of the Arab Bank 2004-2013

\begin{tabular}{llllllll}
\hline y (ROTC) & $\begin{array}{l}\text { Coverage ratio } \\
\text { (Fragility } \\
\text { indicator) }\end{array}$ & $\begin{array}{l}\text { Net Profit } \\
\text { Margin }\end{array}$ & $\begin{array}{l}\text { Capital Ade- } \\
\text { quacy } \\
\text { X6 Deposits }\end{array}$ & $\begin{array}{l}\text { Loans } \\
\text { to Deposits } \\
\text { X3 }\end{array}$ & $\begin{array}{l}\text { Financial } \\
\text { Leverage } \\
\text { X2 }\end{array}$ & $\begin{array}{l}\text { Financial } \\
\text { adequacy } \\
\text { X1 }\end{array}$ & Year \\
\hline 1 & 2 & 3 & 4 & 5 & 6 & 7 & 8 \\
\hline 1.09 & 7.70 & 2.30 & 12.49 & 47.40 & 10.48 & 11.90 & 2004 \\
1.51 & 8.70 & 3.00 & 12.57 & 50.20 & 9.04 & 14.02 & 2005 \\
\hline 1.79 & 9.60 & 3.30 & 13.64 & 59.09 & 5.96 & 23.11 & 2006
\end{tabular}




\begin{tabular}{llllllll}
\hline 1 & 2 & 3 & 4 & 5 & 6 & 7 & 8 \\
\hline 1.96 & 9.20 & 3.40 & 13.65 & 64.21 & 5.98 & 23.07 & 2007 \\
1.97 & 10.20 & 3.30 & 13.63 & 65.84 & 6.35 & 21.74 & 2008 \\
1.41 & 10.50 & 2.50 & 14.14 & 62.51 & 6.07 & 23.43 & 2009 \\
0.94 & 10.30 & 1.40 & 12.42 & 60.86 & 6.16 & 23.00 & 2010 \\
1.40 & 10.10 & 2.63 & 14.45 & 58.18 & 6.27 & 22.18 & 2011 \\
1.47 & 10.10 & 2.63 & 14.11 & 57.81 & 6.17 & 22.54 & 2012 \\
1.87 & 9.80 & 3.30 & 14.15 & 60.06 & 6.20 & 22.54 & 2013 \\
\hline
\end{tabular}

Table 2

Criteria of the Financial Governance of the Jordan Ahli Bank 2004-2013

\begin{tabular}{llllllll}
\hline & Financial & Financial & $\begin{array}{l}\text { Percentage } \\
\text { of Loans to } \\
\text { Year } \\
\text { solvency } \\
\text { X1 }\end{array}$ & $\begin{array}{l}\text { Leverage } \\
\text { X2 }\end{array}$ & $\begin{array}{l}\text { Percentage } \\
\text { of Capital } \\
\text { Adequacy } \\
\text { X3 }\end{array}$ & $\begin{array}{l}\text { Net Profit } \\
\text { margin } \\
\text { X4 }\end{array}$ & $\begin{array}{l}\text { Coverage } \\
\text { ratio } \\
\text { (Fragility } \\
\text { indicator) } \\
\text { X6 }\end{array}$ \\
\hline 2004 & 7.40 & 16.20 & 32.16 & 12.23 & 1.40 & 4.30 & 0.40 \\
2005 & 13.70 & 9.41 & 43.37 & 13.12 & 4.60 & 5.60 & 2.10 \\
2006 & 15.90 & 8.23 & 46.81 & 13.04 & 3.20 & 7.10 & 1.79 \\
2007 & 12.70 & 10.09 & 47.82 & 12.79 & 1.50 & 6.30 & 0.96 \\
2008 & 12.20 & 10.45 & 54.16 & 12.66 & 1.95 & 6.80 & 1.20 \\
2009 & 11.90 & 10.51 & 54.33 & 12.26 & 1.90 & 6.60 & 1.23 \\
2010 & 11.20 & 15.50 & 52.77 & 12.35 & 2.10 & 6.00 & 0.99 \\
2011 & 12.30 & 10.33 & 57.31 & 12.60 & 2.00 & 7.00 & 1.29 \\
2012 & 13.40 & 9.88 & 63.79 & 12.76 & 1.90 & 7.10 & 1.28 \\
2013 & 18.00 & 9.50 & 75.10 & 13.46 & 1.30 & 7.50 & 0.86 \\
\hline
\end{tabular}

Table 3

Criteria of the Financial Governance of the Jordan Kuwaiti Bank 2013-2014

\begin{tabular}{llllllll}
\hline & Financial \\
Year & $\begin{array}{l}\text { Financial } \\
\text { X1 }\end{array}$ & $\begin{array}{l}\text { Peverage } \\
\text { X2 }\end{array}$ & $\begin{array}{l}\text { Loans } \\
\text { to Deposits } \\
\text { X3 }\end{array}$ & $\begin{array}{l}\text { Percentage } \\
\text { of Capital } \\
\text { Adequacy } \\
\text { to Deposits } \\
\text { X4 }\end{array}$ & $\begin{array}{l}\text { Net Profit } \\
\text { margin } \\
\text { X5 }\end{array}$ & $\begin{array}{l}\text { Coverage } \\
\text { ratio } \\
\text { (Fragility } \\
\text { indicator) } \\
\text { X6 }\end{array}$ \\
\hline 2004 & 8.33 & 17.40 & 36.31 & 10.13 & 2.30 & 4.18 & 3.01 \\
2005 & 14.68 & 12.31 & 45.24 & 12.32 & 5.34 & 4.60 & 2.69 \\
2006 & 16.20 & 10.35 & 48.68 & 13.16 & 3.69 & 6.12 & 3.47 \\
2007 & 14.65 & 12.49 & 48.87 & 11.75 & 2.62 & 5.22 & 3.23 \\
2008 & 14.56 & 13.54 & 55.26 & 11.36 & 2.45 & 5.81 & 3.39 \\
2009 & 13.85 & 13.16 & 56.13 & 11.63 & 2.82 & 4.32 & 2.90 \\
2010 & 14.84 & 16.64 & 57.76 & 10.42 & 3.22 & 5.20 & 3.58 \\
2011 & 15.68 & 12.42 & 59.46 & 11.50 & 3.17 & 7.68 & 2.45 \\
2012 & 16.54 & 11.98 & 65.84 & 11.34 & 2.75 & 7.12 & 2.63 \\
2013 & 20.32 & 12.62 & 79.25 & 12.44 & 2.91 & 6.54 & 2.59 \\
\hline
\end{tabular}




\section{Statistical Analysis}

For a statistical analysis, this study adopts the Statistical Analytic Program SPSS, and the testing of the study hypotheses in order to arrive at the results. This study deals with the analysis of the data given in the financial statements of the commercial banks. The chosen sample includes the Arab Bank, the Jordan Ahli Bank, and the Jordan Kuwait Bank.

\section{Presentation of Results and Test of the Hypotheses}

This study aims to investigate the effect of the financial governance on profitability in thirteen Jordanian commercial banks during the period 2004-2013. After collecting the financial reports concerning the banks of the sample of the study, a quantitative curriculum was taken into consideration to study and analyze the data. Financial ratios and formulas were applied as one of the tools of analysis, since it is regarded as the most applicable and suitable to measure the impact of financial governance on profitability. Mathematical means and the standard deviation of the study variables were found during the time of the study for the purpose of having a descriptive analysis during the time sequence. A suitable analysis to test the hypotheses of the study was made.

\section{First: The Descriptive Analysis}

\section{Presentation of the Results of the Analysis}

Tables 4, 5 and 6 show the mathematical means and standard deviations of the main criteria of the financial governance which affect the return on ROTC (the indicator of profitability), and the earnings during the period 2013-2014.

\section{Table 4}

The Mathematical Means and Standard Deviations of the Main Criteria of the Financial Governance which Affect the ROTC (the Indicator of Profitability) in the Arab Bank

\begin{tabular}{lll}
\hline \multirow{2}{*}{ Variables } & Arab Bank & \\
\cline { 2 - 3 } & $\begin{array}{l}\text { The Mathematical } \\
\text { Means }\end{array}$ & Standard Deviations \\
\hline Financial Adequacy & 20.7530 & 4.16661 \\
Financial Leverage & 6.8680 & 1.56612 \\
Loans to Deposits & 58.6160 & 5.80665 \\
Capital Adequacy to Deposits & 13.5250 & 0.76091 \\
Net Profit Margin & 2.7760 & 0.62379 \\
Coverage Ratio & 9.6190 & 0.86708 \\
ROTC & 1.5410 & 0.35551 \\
\hline
\end{tabular}




\section{Table 5}

The Mathematical Means and Standard Deviations of the Main Criteria of the Financial Governance which Affect the ROTC (the Indicator of Profitability) in the Jordan Ahli Bank

\begin{tabular}{llc}
\hline \multirow{2}{*}{ Variables } & \multicolumn{2}{l}{ Jordan Ahli Bank } \\
\cline { 2 - 3 } & The Mathematical Means & Standard Deviations \\
\hline Financial Adequacy & 12.8700 & 2.80715 \\
Financial Leverage & 11.0100 & 2.64184 \\
Loans to Deposits & 52.7620 & 11.63425 \\
Capital Adequacy to Deposits & 12.7270 & 0.39758 \\
Net Profit Margin & 2.1850 & 0.99946 \\
Coverage ratio & 6.4300 & 0.94051 \\
ROTC & 1.2100 & 0.47490 \\
\hline
\end{tabular}

\section{Table 6}

The Mathematical Means and Standard Deviations of the Main Criteria of the Financial Governance which Affect the ROTC (the Indicator of Profitability) in the Jordan Kuwaiti Bank

\begin{tabular}{lcc}
\hline \multirow{2}{*}{ Variables } & \multirow{2}{*}{ Jordan Kuwaiti Bank } \\
\cline { 2 - 3 } & The Mathematical Means & Standard Deviations \\
\hline Financial Adequacy & 17.4100 & 3.36863 \\
Financial Leverage & 8.4630 & 2.41248 \\
Loans to Deposits & 74.2630 & 6.07218 \\
Capital Adequacy to Deposits & 13.8490 & 1.09330 \\
Net ProfitMargin & 3.8520 & 0.39035 \\
Coverage ratio & 7.7270 & 1.50995 \\
ROTC & 2.9940 & 0.40492 \\
\hline
\end{tabular}

\section{Second: Test of the Hypotheses}

\section{Test of the Main Hypothesis}

There is no relationship with a statistical significance between the financial governance and the profitability of the commercial banks in Jordan. Tables 10, 11, and 12 show the results of the multiple linear regression of the main criteria of the financial governance which affect the return on the total capital (the indicator of profitability).

Table 7 illustrates the results of the multiple linear regressions of the main criteria of the financial governance which affect the return on total capital (the indicator of profitability) in the Arab Bank. In the analysis of the Arab Bank data, it seems that there is a relationship with a statistical significance between the financial governance and the return on total capital (the indicator of profitability) where the value of $F$ is (68.091) which are at the level of 
the indication of Sig. F (.003) lower than (.05). So, we reject the zero hypotheses and accept the substitute or alternative hypothesis which points out a relationship with a statistical significance between the financial governance and the profitability of the Jordanian commercial banks. It also shows that the value of the modulus of determination $\mathrm{R}^{\wedge} 2$ (.996). That is, the criteria of financial governance explain what constitutes $(99.6 \%)$ of the results of the ROTC (indicator of profitability).

\section{Table 7}

Analysis of the Multiple Linear Regression of the Main Criteria of the Financial Governance which Affect the Return On Total Capital (the indicator of profitability) in the Arab Bank

\begin{tabular}{llll}
\hline $\mathrm{R}$ & $\mathrm{R}^{\wedge} 2$ & $\mathrm{~F}$ & Sig. F \\
\hline 0.996 & 0.993 & 68.091 & 0.003 \\
\hline
\end{tabular}

\section{Table 8}

Analysis of the Multiple Linear regression of the Main Criteria of Financial Governance which

Affect the Return On Total Capital (the indicator of profitability) in the Jordan Ahli Bank

\begin{tabular}{llll}
\hline $\mathrm{R}$ & $\mathrm{R}^{\wedge} 2$ & $\mathrm{~F}$ & Sig. F \\
\hline 0.999 & 0.998 & 265.013 & 0.000 \\
\hline
\end{tabular}

Table 8 illustrates the results of the multiple linear regressions of the main criteria of the financial governance which affect the return on total capital in the Jordan Ahli Bank. In the analysis of the Jordan Ahli Bank data, it seems that there is a relationship with a statistical significance between the financial governance and the return on total capital where the value of F is (265.013) which are at the level of the indication of Sig. F (.000) lower than (.05). So, we reject the zero hypotheses and accept the substitute or alternative hypothesis which points out a relationship with a statistical significance between the financial governance and the profitability of the Jordanian commercial banks. It also shows that the value of the modules of limitation is $\mathrm{R}^{\wedge} 2$ (.998).

That is the criteria of financial governance which explains what constitutes $(99.8 \%)$ of the results of ROTC (indicator of profitability).

\section{Table 9}

Analysis of the Multiple Linear regression of the Main Criteria of the Financial Governance which Affect the Return On Total Capital (the indicator of profitability) in the Jordan Kuwaiti Bank

\begin{tabular}{llll}
\hline $\mathrm{R}$ & $\mathrm{R}^{\wedge} 2$ & $\mathrm{~F}$ & Sig. F \\
\hline 0.963 & 0.927 & 6.347 & 0.079 \\
\hline
\end{tabular}


Table 9 illustrates the results of the multiple linear inclinations of the main criteria of the financial governance which affect the return on total capital in the Jordan Kuwaiti Bank. In the analysis of the Jordan Kuwaiti Bank data, it seems that there is a relationship with a statistical significance between the financial governance and ROTC where the value of $\mathrm{F}$ is (6.347) which is at the level of the indication of Sig. F (.079) lower than (.05). So, we reject the zero hypotheses and accept the substitute or alternative hypothesis which points out a relationship with a statistical significance between the financial governance and the profitability of the Jordanian commercial banks. It also shows that the value of the modulus of limitation is $\mathrm{R}^{\wedge} 2$ (.927). That is the criteria of financial governance which explains what constitutes $(92.7 \%)$ of the results of the ROTC.

\section{Test of then Subsidiary Hypothesis}

\section{The First Hypothesis}

There is no relationship with a statistical significance between the variable of financial adequacy and the profitability of the commercial banks in Jordan.

\section{The Second Hypothesis}

There is no relationship with a statistical significance between the variable financial leverage and the profitability of the commercial banks in Jordan.

\section{The Third Hypothesis}

There is no relationship with a statistical significance between the variable of loans to deposits and the profitability of the commercial banks in Jordan.

\section{The Fourth Hypothesis}

There is no relationship with a statistical significance between the variable of the capital adequacy to deposits and the profitability of the commercial banks in Jordan.

\section{The Fifth Hypothesis}

There is no relationship with a statistical significance between the variable net profit margin and the profitability of the commercial banks in Jordan.

\section{The Sixth Hypothesis}

There is no relationship with a statistical significance between the variable of coverage ratio and the profitability of the commercial banks in Jordan.

Tables 10, 11, and 12 present the results of the simple linear regression to the main criteria of the financial governance that affect ROTC.

Table 10 illustrates the results of the simple linear regression to the main criteria of the financial governance that affect the ROTC in the Arab Bank. In the analysis of the Arab Bank data, it seems that there is no relationship with a statistical significance between independent variables: financial adequacy, financial leverage, loans to deposits, the capital adequacy to deposits, coverage ratio and the return on total capital (the indicator of profitability) where the value of Sig. F of each of the previous variables are more than $(0.05)$; whereas there is a relationship with a statistical significance between the financial leverage and the net profit 
margin, and the return on total capital (the indicator of profitability) where the value of Sig. $\mathrm{F}$ is (0.000) which is less than (0.05). That is, there is efficiency of management of the return on the total capital.

\section{Table 10}

Analysis of the simple linear inclination to the main criteria of the financial governance that affect the return on total capital (indicator of profitability) in the Arab Bank

\begin{tabular}{lllrl}
\hline Criteria of financial governance & $\mathrm{R}$ & $\mathrm{R}^{\wedge} 2$ & \multicolumn{1}{l}{$\mathrm{F}$} & Sig. F \\
\hline Ratio of Financial Adequacy & 0.356 & 0.126 & 1.158 & 0.313 \\
Ratio of Financial Leverage & 0.414 & 0.171 & 1.651 & 0.235 \\
Ratio of Loans to Deposits & 0.518 & 0.268 & 2.927 & 0.125 \\
Ratio of Capital Adequacy to Deposits & 0.509 & 0.259 & 2.80 & 0.133 \\
Ratio of the Net Profit Margin & 0.947 & 0.898 & 70.131 & 0.000 \\
Ratio of the Average of Coverage & 0.143 & 0.020 & 0.167 & 0.693 \\
\hline
\end{tabular}

Table 11 presents the results of the simple linear regression to the main criteria of the financial governance that affect the return on total capital in the Jordan Ahli Bank. In the analysis of the Jordan Ahli Bank, it seems that there is no relationship with a statistical significance between the financial adequacy, loans to deposits, capital adequacy to deposits, coverage ratio and the return on total capital where the value of Sig. F of each of the previous variables are more than $(0.05)$; whereas there is a

\section{Table 11}

Analysis of the simple linear regression to the main criteria of the financial governance that affects the return on total capital in the Jordan Ahli Bank

\begin{tabular}{lllrl}
\hline Criteria of the financial governance & $\mathrm{R}$ & $\mathrm{R} \wedge 2$ & $\mathrm{~F}$ & Sig. F \\
\hline Ratio of Financial Adequacy & 0.460 & 0.212 & 2.148 & 0.181 \\
Ratio of Financial Leverage & 0.674 & 0.454 & 6.650 & 0.033 \\
Ratio of Loans to Deposits & 0.011 & 0.000 & 0.001 & 0.976 \\
Ratio of Capital Adequacy to Deposits & 0.428 & 0.184 & 1.798 & 0.217 \\
Ratio of the Net Profit Margin & 0.898 & 0.806 & 33.270 & 0.000 \\
Ratio of the Average of Coverage & 0.303 & 0.092 & 0.812 & 0.394 \\
\hline
\end{tabular}

Relationship with a statistical significance between the financial leverage, the net profit margin, and the return on total capital where the value of Sig. F is less than (0.05). That is, there is an efficiency of management of the total capital, and efficiency in exploiting the funds that come from debt. But, the effect of the net profit margin on the indicator of profitability is greater than the effect of the financial leverage where Sig. F. of the net profit is $(0.000)$, whereas the Sig. F. of the financial leverage is (0.033). 


\section{Table 12}

Analysis of the simple linear inclination to the main criteria of the financial governance that affects the return on total capital (indicator of profitability) in the Jordan Kuwaiti Bank

\begin{tabular}{lllll}
\hline Criteria of the financial governance & $\mathrm{R}$ & $\mathrm{R}^{\wedge} 2$ & $\mathrm{~F}$ & $\mathrm{Sig} . \mathrm{F}$ \\
\hline Financial Ability & 0.050 & 0.002 & 0.020 & 0.891 \\
Financial Leverage & 0.046 & 0.002 & 0.017 & 0.900 \\
Percentage of Loans to Deposits & 0.247 & 0.061 & 0.518 & 0.492 \\
Percentage of Capital Adequacy to Deposits & 0.435 & 0.189 & 1.864 & 0.209 \\
Percentage of the Margin of Net Profit & 0.891 & 0.794 & 30.867 & 0.001 \\
Percentage of the Average of Covering & 0.123 & 0.015 & 0.123 & 0.734 \\
\hline
\end{tabular}

Table 12 illustrates the results of the simple linear inclination to the main criteria of the financial governance that affect the return to the turnover capital (indicator of profitability) in the Jordan Kuwaiti Bank. In accordance with the analysis of the Jordan Kuwaiti Bank data, it seems that there is no relationship with a statistical significance between the financial solvency, financial leverage, the percentage of loans to deposits, the percentage of the capital adequacy to deposits, coverage ratio and the return on total capital (the indicator of profitability) where the value of Sig. F of each of the previous variables are more than (0.05); whereas there is a relationship with a statistical significance between the financial leverage and the net profit margin, and the return on total capital (the indicator of profitability) where the value of Sig. F is (0.001) which is less than (0.05). That is, there is competence of management of the turnover of the capital.

To confirm the results of the previous analyses and for the purpose of showing the importance of every independent variable in expecting the following variable, the two samples of the complete multiple linear inclinations (Full Model-F.M) and the restricted multiple linear inclination (Restricted Model-R.M.) are applied as follows:

Throughout the analysis of the restricted samples of the Arab Bank, it seems that:

- when deleting the variable of financial solvency (x1) from the sample, the $\mathrm{R}^{\wedge} 2$ remains as it is, i.e. (0.998). That is, the criterion of the financial ability is not important in the expectation of the return to the turnover $(y)$;

- when deleting the variable of the financial leverage $(\mathrm{x} 2)$ from the sample, the $\mathrm{R}^{\wedge} 2$ remains as it is, i.e. (0.993). That is, the criterion of the financial leverage is not important in the expectation of the return to the turnover $(\mathrm{y})$;

- when deleting the variable of the percentage of loans to deposits (x3) from the sample, the $\mathrm{R}^{\wedge} 2$ drops little and becomes (0.982). That is, the criterion of the percentage of loans to deposits is weak in the expectation of the return to the turnover (y); 
- when deleting the variable of the percentage of the capital adequacy to deposits ( $\mathrm{x} 4)$ from the sample, the $\mathrm{R}^{\wedge} 2$ drops little and becomes $(0.991)$. That is, the criterion of the percentage of loans to deposits is weak in the expectation of the return to the turnover (y);

- when deleting the variable of the net profit margin ( $\mathrm{x} 5$ ) from the sample, the $\mathrm{R}^{\wedge} 2$ drops little and becomes $(0.890)$. That is, the criterion of the margin of net profit is strong in the expectation of the return to the turnover $(\mathrm{y})$;

- when deleting the variable of coverage ratio (x6) from the sample, the $\mathrm{R}^{\wedge} 2$ remains as it is, i.e. (0.993). That is, the criterion of the average of covering is not important in the expectation of the return to the turnover $(\mathrm{y})$.

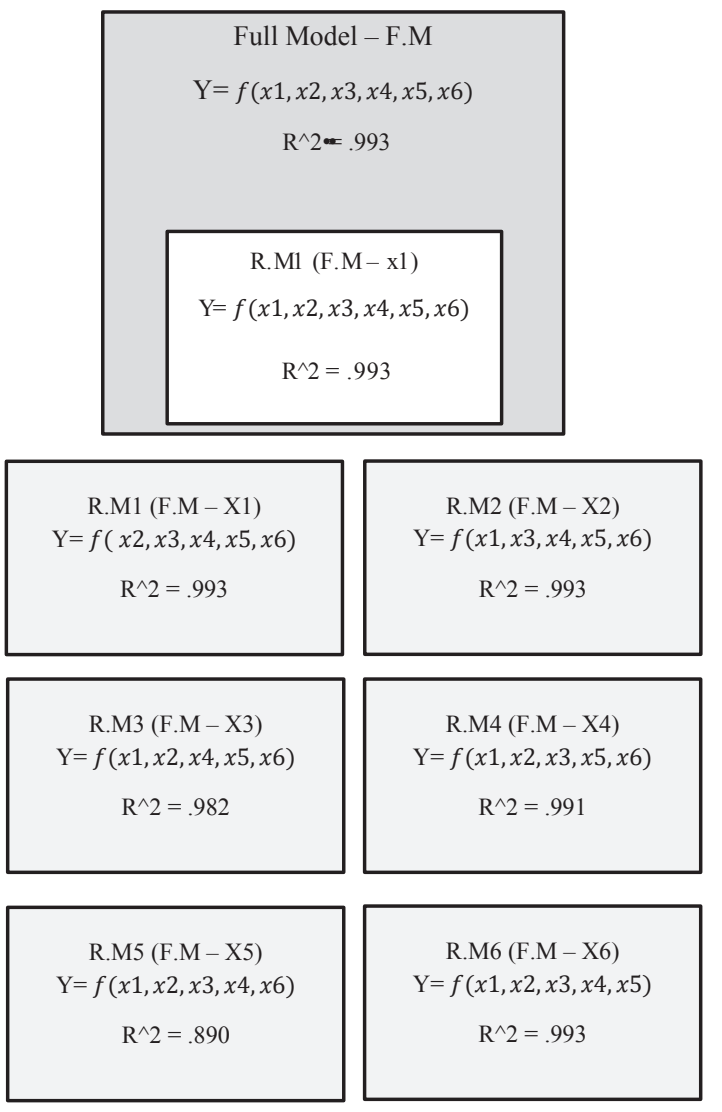

Figure 2. The Sample of the Complete Multiple Linear Inclination (Full Model-F. M), and the Sample of the Restricted Multiple Linear Inclination (Restricted Model-R.M.) of the Arab Bank 


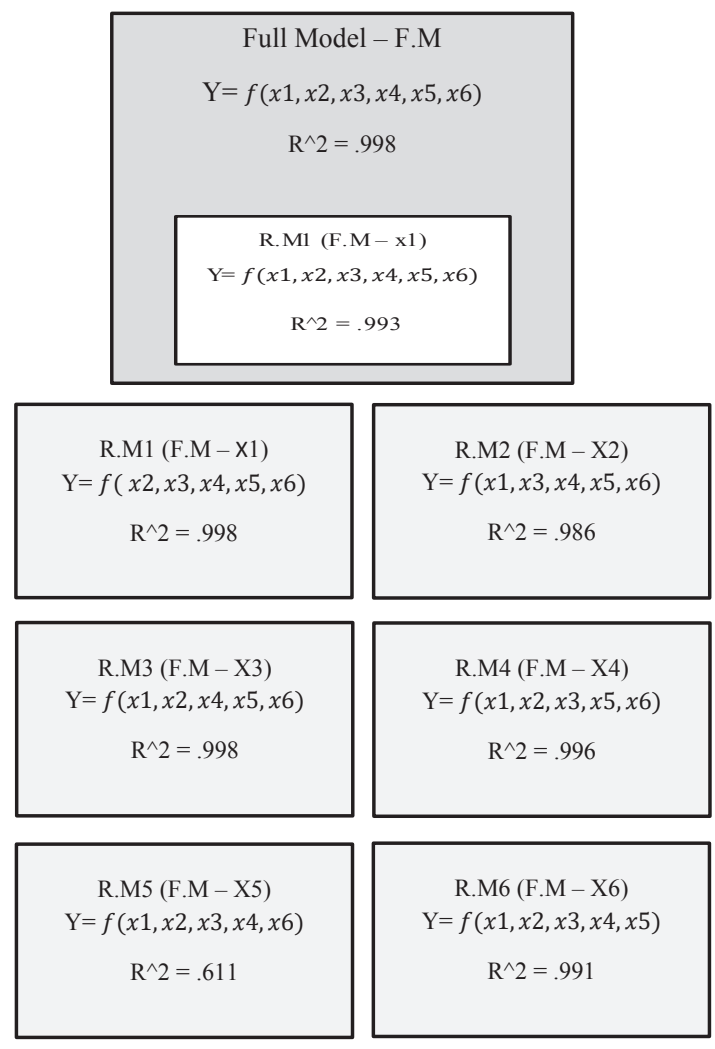

Figure 3. The Sample of the Complete Multiple Linear Inclination (Full Model-F. M), and the Sample of the Restricted Multiple Linear Inclination (Restricted Model-R.M.) of the Jordan Ahli Bank

Throughout the analysis of the restricted samples of Jordan Ahli Bank, it seems that:

- when deleting the variable of financial solvency $(\mathrm{x} 1)$ from the sample, the $\mathrm{R}^{\wedge} 2$ remains as it is, i.e., (0.993). That is, the criterion of financial ability is not important in the expectation of the return to the turnover (y);

- when deleting the variable of financial leverage (x2) from the sample, the $\mathrm{R}^{\wedge} 2$ drops little and becomes (0.986). That is, the criterion of financial leverage is weak in the expectation of the return to the turnover $(\mathrm{y})$;

- when deleting the variable of the percentage of loans to deposits (x3) from the sample, the $\mathrm{R}^{\wedge} 2$ drops little and becomes $(0.998)$. That is, the criterion of the percentage of loans to deposits is not important in the expectation of the return to the turnover (y);

- when deleting the variable of the percentage of the capital adequacy to deposits $(\mathrm{x} 4)$ from the sample, the $\mathrm{R}^{\wedge} 2$ drops little and becomes $(0.996)$. That is, the criterion of the 
percentage of the capital adequacy to deposits is weak in the expectation of the return to the turnover $(\mathrm{y})$;

- when deleting the variable of the net profit margin (x5) from the sample, the $\mathrm{R}^{\wedge} 2$ drops little and becomes (0.611). That is, the criterion of the margin of the net profit is strong in the expectation of the return to the turnover (y);

- when deleting the variable of coverage ratio (x6) from the sample, the $\mathrm{R}^{\wedge} 2$ drops little and becomes (0.991). That is, the criterion of the average of covering is weak in the expectation of the return to the turnover $(\mathrm{y})$.

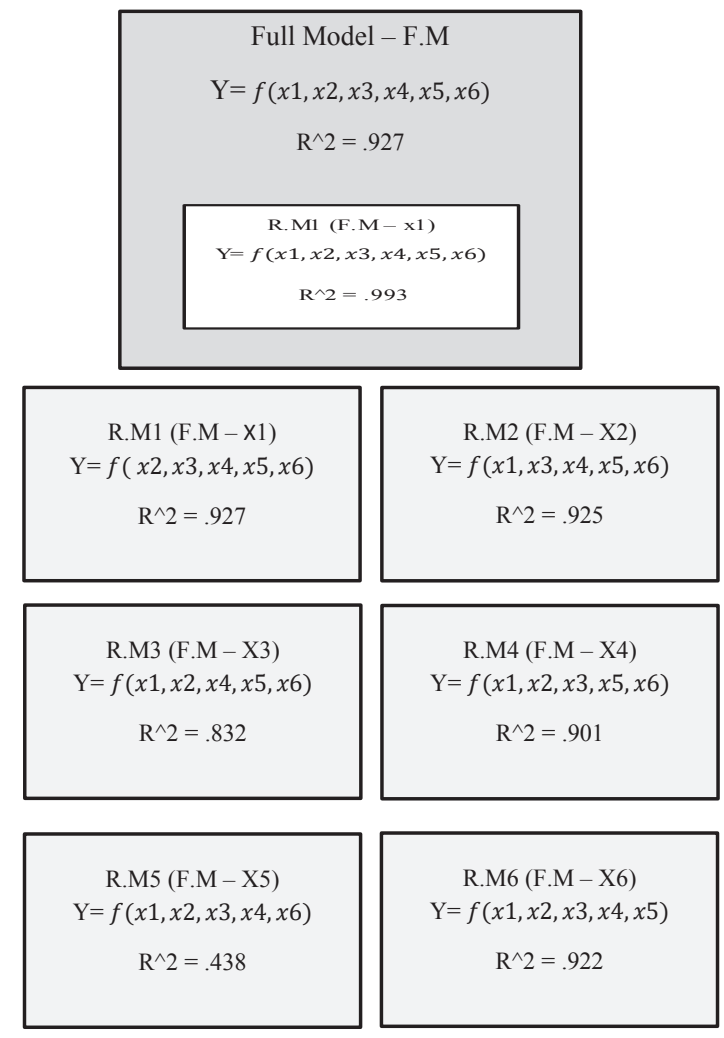

Figure 4. The Sample of the Complete Multiple Linear Inclination (Full Model-F. M), and the Sample of the Restricted Multiple Linear Inclination (Restricted Model-R.M.) of the Jordan Kuwaiti Bank

Throughout the analysis of the restricted samples of the Jordan Kuwaiti Bank, it seems that:

- when deleting the variable of financial solvency $(\mathrm{x} 1)$ from the sample, the $\mathrm{R}^{\wedge} 2$ remains as it is, i.e., (.927). That is, the criterion of financial ability is not important in the expectation of the return to the turnover $(\mathrm{y})$; 
- when deleting the variable of financial leverage (x2) from the sample, the $\mathrm{R}^{\wedge} 2$ drops little and becomes (.925). That is, the criterion of financial leverage is weak in the expectation of the return to the turnover $(\mathrm{y})$;

- when deleting the variable of the percentage of loans to deposits (x3) from the sample, the $\mathrm{R}^{\wedge} 2$ drops little and becomes (.832). That is, the criterion of the percentage of loans to deposits is weak in the expectation of the return to the turnover $(y)$;

- when deleting the variable of the percentage of the capital adequacy to deposits $(\mathrm{x} 4)$ from the sample, the $\mathrm{R}^{\wedge} 2$ drops little and becomes (.901). That is, the criterion of the percentage of loans to deposits is weak in the expectation of the return to the turnover $(\mathrm{y})$;

- when deleting the variable of the net profit margin (x5) from the sample, the $\mathrm{R}^{\wedge} 2$ drops little and becomes (.438). That is, the criterion of the margin of the net profit is strong in the expectation of the return to the turnover $(\mathrm{y})$;

- when deleting the variable of coverage ratio (x6) from the sample, the $\mathrm{R}^{\wedge} 2$ drops little and becomes (.922). That is, the criterion of the average of covering is weak in the expectation of the return to the turnover $(\mathrm{y})$.

\section{Conclusions and Recommendations}

\section{First: Conclusions/Results}

This study arrived at the following conclusions and results:

1. The results of the analysis of the multiple linear inclination of the financial percentages of the Arab Bank and Jordan Ahli Bank show that there is relationship with a statistical significance between the financial governance and profitability in the Jordanian commercial banks at the level (0.05), whereas results of the analysis of the multiple linear inclination of the financial percentages of the Jordan Kuwaiti bank indicate that there is no relationship with a statistical significance between the financial governance and profitability in the Jordanian commercial banks at the level (0.05).

2. The results of the analysis of the simple linear inclination of the financial percentages of the Arab Bank show that there is no relationship between the financial solvency, the financial leverage, the percentage of loans to deposits, the percentage of the capital adequacy to deposits, coverage ratio and the return on total capital (the indicator of profitability), whereas there is a relationship with a statistical significance between the net profit margin and the return on total capital (the indicator of profitability).

3. The results of the analysis of the simple linear inclination of the financial percentages of the Jordan Ahli Bank indicate that there is no relationship between the financial solvency, the financial leverage, the percentage of loans to deposits, the percentage of the capital adequacy to deposits, cover ageratio and the return on total capital (the indicator of profitability), whereas there is a relationship with a statistical significance between the net profit 
margin and the return on total capital (the indicator of profitability), but the effect of the net profit margin on the indicator of profitability is greater than the effect of financial leverage on the indicator of profitability.

4. The results of the analysis of the simple linear inclination of the financial percentages of the Jordan Kuwaiti Bank indicate that there is no relationship between the financial solvency, the financial leverage, the percentage of loans to deposits, the percentage of the capital adequacy to deposits, coverage ratio and the return on total capital (the indicator of profitability), whereas there is a relationship with a statistical significance between the net profit margin and the return on total capital (the indicator of profitability).

\section{Second: Recommendations}

In the light of the above mentioned conclusions, below are some recommendations:

1. There should be financial governance in the Jordan commercial banks, since it plays an effective role in reducing the sequences of economic crises.

2. The bodies of censorship and supervision on banks represented by The Central Bank should pay special attention to encouraging banks to apply the system of financial governance. Such bodies should issue a guidebook of the basic principles of this system which helps motivating banks to apply it.

3. Spreading the culture of the financial governance among the members of the banks' administrative councils, their top management, and all officers, is urgent for the purpose of securing dominance of a culture that embraces the principles of financial governance.

4. It is essential to have training programs that help to practice the application of different styles of governance.

5. Teaching the topic of 'Financial Governance' as an academic course in undergraduate and postgraduate programs of Jordanian and Arab universities is one more important issue because of its modernity in academic and economical areas in particular, and because of its impact on banks in general.

6. It is necessary to carry out more and more studies and research on the impact of financial governance on the profitability in commercial banks throughout current variables and for long periods of time so as to know the most influential criteria of financial governance on profitability.

\section{References}

Abdul-Haleem M. (2005). "Governance of Banks". The Fifth Conference on Corporations' Governance and its Counting, Administrative and Economical Dimensions, First Part, Alexandria University, Faculty of Trade.

Abu-Sharar A. (2012). The International Financial and Economical Crisis: Its Events, Reasons, Collapses and Procedures.

Al-Ghunaimi, M. (2005). "Governance and the Banking Body" The Fifth Conference on Corporations'Governance and its Counting, Administrative and Economical Dimensions, First Part, Alexandria University, Faculty of Trade. 
Al-Hanini (2004). Developing the System of Establishment Governance in the Public Jordanian Sharing Establishments. A Dissertation, Amman Arab University.

Ali A., Shhata Sh. (2005). Revision of Accounts and Corporations 'Governance in the Environment of Contemporary Arabian and International Business. Ad-Dar Al-Jamiyah, Alexandria.

Al-Khalidi H. (2008). The Effect the Internal Techniques of Governance on Performance and Banking Risks to a Sample of Iraqi Civil Banks. Un-Published Dissertation.

Al-Shunnaq Sh. (2009). Declaration of Corporations ' Governance and the Financial Performance: An Applied Study on the Jordanian Commercial Banks. An A.M. Thesis, Yarmouk University, Irbid.

Bilal M. (2005). "The Role of Censorship of the quality of Revision in achieving the Goals of Corporations' Governance", The Fifth Conference on Corporations 'Governance and its Counting, Administrative and Economical Dimensions, First Part, Alexandria University, Faculty of Trade.

Centre of Abu-Dhabi for Governance. (2013). "Terms and Concepts" A Series of Intellectual Bulletins of the Centre of Abu-Dhabi for Governance. Abu-Dhabi Room, Abu-Dhabi.

Fawzy S. (2003). "Assessment of corporation governance in Egypt”, working paper No. 82, the Egyptian center for economic studies, Egypt.

Hafnawi Sh. (2005). Corporations' Governance and its Role in Remedying the Diseases of Counting Thought and Application, $2^{\text {nd }}$ Part.Alexandria University, Faculty of Trade.

Hammad T. (2005). Corporations' Governance (Concepts-Principles-Experiments: Applications of Governance in Banks. Ad-Daar Al-Jamiyah, Alexandria.

http//www.ase.com.jo/ar.

http://jamahir.alwwehda.gov.sy.

Jawdah A. (2008). The Extent of the Application of the Principles of Establishment Governance in the Palestinian Banks in Accordance with the Principles of the Organization of Development and Economic Cooperation, and the Principles of Basil Organization of Bank Observation. An M.A. Thesis, The Islamic University of Gaza, Gaza.

Journal of Financial and Banking Studies, Issue No. 82. (2013). The Arab Academy of Financial and Banking Sciences.

Khuri N. (2006). “ Transparency and Governance in Corporations”, Journal of Al-Mashriq. Issue No. 68, Society of Jordanian Lawful Auditors.

Matar M., Noor A. (2007). "The Extent of the Commitment of the Jordanian General Corporations in the Principles of the Establishment Governance: An Analytic Contrastive Study Between Industrial and Banking Sectors." The Jordanian Journal of Business Administration, Volume No. 3. Jordan University.

Salam M. (2014). Corporation and their Role in Attracting Foreign Investments and Achievement of Permanent Development. Dar An-Nahda, Cairo.

Stickney C. (1990) "Financial statement analysis: a strategic perspective, Sandiego, USA.

Sulaiman M. (2006). Corporations' Governance and Treatment of Financial and Administrative Corruption: A Contrastive Study. Ad-Daar Al-Jamiyah, Alexandria.

Syam A. (2009). "The Role of Banking Governance in Enhancing the Competence of Jordanian Commercial Banks." $2^{\text {nd }}$ Scientific Conference, Faculty of Business Administration, Balqa Applicable University.

Yahyawi N., Bu Salama H. (2012). "The Role of Establishment Governance in Improving the Financial Performance of Corporations". The National Assembly about Corporations' Governance as a Technique of Curbing Financial and Administrative Corruption.

\section{WPLYW LADU FINANSOWEGO NA RENTOWNOŚĆ BANKÓW KOMERCYJNYCH W JORDANII (W OKRESIE 2004-2013)}

Streszczenie: Celem przeprowadzonego badania było poznanie zakresu zastosowania zasad ładu finansowego w jordańskich bankach komercyjnych oraz zmierzenie wpływu tych zasad na rentowność banków z zastosowaniem niektórych narzędzi zarządzania finansami, takich jak dźwignia finansowa, stosunek kredytów do depozytów, adekwatności kapitałowej do depozy tów, marża zysku netto i wskaźnik pokrycia. Badaniem objęto trzynaście jordańskich banków komercyjnych. Próba badawcza obejmuję trzy banki komercyjne o małym, średnim i dużym poziomie kapitałów w latach 2004-2013. Do analizy danych wykorzystano program 
SPSS. Dane finansowe zaczerpnięto z raportów rocznych badanych banków, zamieszczonych na stronach internetowych giełdy papierów wartościowych w Ammanie. W badaniu wykorzystano metodę wydobywania metadanych. W celu sprawdzenia rozkładu normalnego danych zastosowano odchylenie standardowe. Ponadto, wykorzystano również macierz korelacji Pearsona i testy stabilności danych. Na koniec zastosowano prostą regresję liniową, analizę wieloraką i przetestowano wpływ składnika losowego.

Słowa kluczowe: rentowność, banki komercyjne, zarządzanie finansami

\section{Citation}

Al Zararee A.N., Sinno O. (2016). The Impact of Financial Governance on Profitability in Jordanian Commercial Banks (During the Period 2004-2013). Finanse, Rynki Finansowe, Ubezpieczenia, 4 (82/2), $723-747$. DOI: $10.18276 /$ frfu. 2016.4.82/2-63. 